\title{
Evolution of Monetary and Exchange Rate Policy in Sri Lanka and the Way Forward
}

\author{
Olcott Oration, 18 November 2017 \\ at Ananda College - Kularatne Auditorium
}

\author{
P. Nandalal Weerasinghe 1 \\ Senior Deputy Governor, Central Bank of Sri Lanka
}

\begin{abstract}
Preamble
I am deeply honoured to have been invited to deliver the Olcott Oration 2017 and to join a list of great Anandians who have delivered this Oration before. I cannot think of a greater honour that my school could confer on me. I accepted this invitation with bumbleness, with gratitude and respect, and with great pride. Let me also take this opportunity to appreciate the support and guidance I received during my school career at Ananda College. The guidance our teachers gave us laid the foundation for any success later on in our lives.

My oration today, is on the rather technical topic of monetary and exchange rate policy. The biggest challenge that I have to face is to present such a topic to an audience with a majority who might not be familiar with the technical jargon involved. However, I will attempt to keep the discussion as simple as possible.
\end{abstract}

Key Words: Monetary Policy, Exchange Rate Policy, Central Banking, Sri Lanka JEL Classification: E5; N1

\footnotetext{
${ }^{1}$ I would like to note that the views expressed in this oration are my own as an economist and do not necessarily reflect the views of the Central Bank of Sri Lanka. I also would like to acknowledge the technical support received in preparing the oration from Dr Chandranath Amarasekara and his team at the Economic Research Department of the Central Bank of Sri Lanka.
} 


\section{Central Banking and Price Stability}

The prime responsibility of any central bank around the world is to maintain price stability by way of maintaining low and stable inflation on a sustainable basis. At the outset, I would like to discuss why low and stable inflation is important for growth and stability of the economy.

Based on experiences of many countries and different time periods, we have seen varying levels of inflation. When countries experience hyperinflation, domestic prices of goods and services will rise every minute. In such a situation, no one will want to hold the local currency, and people will rush straight from the bank to the shops to buy goods, fearing that their currency holding will lose value along the way. In fact, the banking system itself will collapse. As people lose faith in local currency, the barter system, or the exchange of goods for goods or services will become the norm, making transactions significantly more difficult. Hyperinflation will also cause adverse redistributive effects, destroying real value of middle class savings in local currency and real incomes of fixed income earners such as workers and pensioners. One can read horror stories of hyperinflation in Germany and Australia in the 1920s, and more recently in several Latin American countries and also in countries like Zimbabwe. The episode of hyperinflation in the inter-war Germany is said to have facilitated the rise of Hitler and the global destruction that followed. The famous economics author Neil Irwin, in his book titled "The Alchemists: Three Central Bankers and a World on Fire", called the Governor of the German Reichsbank at the time, the "worst central banker in history"!

Let us also look at the other extreme case of price movements, namely deflation. The example that will come to anyone's mind is Japan, which underwent what was known as the "lost decade". Now it is termed the "lost 20 years"! Since early 1990s Japan experienced deflation, a continued decline in prices of goods and services. One may think that this is great! But what could be considered good for a consumer in the short-term may not be good for the entire economy, as evidenced by the experience of Japan. Since then, the Japanese economy had experienced negative economic growth, a drop in nominal GDP, declining wages and negative interest rates! Some indications of sustained growth in Japan are seen only now.

Fortunately, Sri Lanka has never experienced such episodes in the past, and clearly we want neither hyperinflation nor deflation even in the future. But what about double-digit inflation hovering around 10-20 per cent, as experienced in Sri Lanka for several decades from 1970s? Empirical evidence clearly shows that this kind of double digit inflation is bad for sustained growth. High and volatile inflation causes lenders like banks and other financial institutions to demand a higher fixed interest rate on loans to compensate for the risk that inflation will move around, thus raising the cost of finance for investment. At the same time, financial institutions need to offer higher nominal and real interest rates to encourage savers to deposit their money to mitigate the risk of high and volatile inflation eroding the real value of their savings. High and volatile inflation increases the margin between lending rates and deposits, and this high cost of financial intermediation penalises both savers and borrowers. High and volatile 
inflation encourages workers to bargain for higher wages. High and volatile inflation also prompts producers and sellers in the economy to add higher markups in pricing of goods and services. The combined result of this self-fulfilling cycle will be lower economic growth and higher current account deficits, depleting reserves and volatile exchange rates, and the country will end up with a commercial capitalist class of buyers and sellers of imported goods, or a class of middlemen!

Then the question is, what is the appropriate level of low and stable inflation, which will result in more desirable outcomes? Most advanced economies set their inflation target in the low single digits around 2 per cent. For example, the United States and the United Kingdom desire to maintain inflation at around 2 per cent, while in the Eurozone it is below but close to 2 per cent. Australia has an inflation target of 2-3 per cent, and in New Zealand it is 1-3 per cent. Within emerging market and developing economies, the targets are slightly higher. The Philippines and Chile target 2-4 per cent, Indonesia 2.5-4.5 per cent, Brazil 4.5 per cent, South Africa 3-6 per cent, while India targets 2-6 per cent of inflation.

It must be noted here that a central bank could only effectively control demand driven inflation. Central banks could do little to address short-term disruptions to prices due to adverse domestic supply developments or unexpected international commodity price movements. However, central bank responses will be required to contain demand driven inflation, usually identified by movements in core inflation indices.

\section{Monetary Policy Frameworks}

In order to maintain low and stable, single digit inflation, central banks around the world are entrusted with the task of conducting monetary policy with varying degrees of independence. Central banks use various monetary policy frameworks, as there needs to be a mechanism to operationalise the achievement of the end objective of price stability using the policy tools given to central banks to fulfil this task.

Monetary policy frameworks differ across countries depending on country-specific circumstances such as the level of financial market sophistication, openness of the economy, strengths, capacities and independence of institutions, etc. For example, monetary policy frameworks in some countries are based on currency board arrangements where the value of domestic currency is strictly pegged to an international currency. In currency board arrangements, domestic inflation is directly linked to inflation of the country of which its currency is pegged, and then the anchor for inflation will be the exchange rate. In such strict exchange rate targeting regimes, the country's business cycles in terms of growth and inflation would be fully synchronised with the other country's business cycles. In these countries, monetary authorities have very little leeway to use monetary policy as a countercyclical policy measure to stabilise growth and inflation in the domestic economy. In the other extreme end, 
monetary policy frameworks are based on fully fledged inflation targeting regimes where inflation is directly anchored through inflation targets and interest rate policy, while maintaining fully floating exchange rates. Under this arrangement, the exchange rate acts as the shock absorber to minimise the impact of external shocks on the real economy. In such regimes, central banks have more autonomy to use interest rates as an instrument to counter any cyclical economic shocks. There are many central banks that have a combination of these two extremes, where some are closer to inflation targeting and others being closer to exchange rate targeting with soft pegs with some leeway to use interest rate as an instrument to manage inflation and growth. One cannot argue that one regime is superior to the other. It all depends on country circumstances, and even within one country, monetary policy frameworks move in different directions at different times. Monetary aggregate targeting frameworks fall between these two extreme regimes depending on the extent of exchange rate flexibility of such policy regimes.

\section{Evolution of Monetary Policy Framework in Sri Lanka}

Sri Lanka's monetary policy framework has also evolved from a currency board arrangement before the establishment of the Central Bank of Sri Lanka in 1950. This history has been well covered in the masterpiece, "From dependent currency to central banking in Ceylon" written by Professor H A de S Gunasekera, in whose honour my retired senior central bank colleague Sirimevan Colombage delivered an eloquent speech recently at the University of Peradeniya.

From 1950 to 1977 Sri Lanka's monetary policy framework was largely based on maintaining a fixed exchange rate regime in terms of fixing the value of Sri Lanka rupee first to the sterling pound and then to the US dollar. Under this fixed exchange rate regime, domestic inflation was directly linked to foreign inflation and therefore there was no need for an explicit monetary anchor to manage inflation. The Central Bank did not have much leeway to control domestic inflation as the fixed exchange rate was the anchor to manage inflation. Like many other things, inflation was also more or less imported from the United Kingdom those days!

This system worked well as long as Sri Lanka earned sufficient foreign exchange to meet expenditure on imports without any restriction. For example, during the periods of export booms particularly in the early 1950s, the fixed exchange rate regime worked well, as foreign exchange earnings, which arose due to external factors rather than domestic export promoting policies, were not only sufficient to meet current expenditure but also helped build up foreign reserves so that currency peg could be maintained without foreign grants or borrowings. The necessary condition for any country to maintain a currency peg with a strong reserve currency like sterling pound on a sustainable basis is the country's ability to earn sufficient foreign exchange. In other words, such a country would require a strong set of export oriented policies. In technical terminology, a country should run at least a balanced current account in the 
balance of payments on a long-term basis for it to be able to maintain a peg with a strong foreign currency. Economies like Japan early on, and later Hong Kong, Singapore, Taiwan and even China, given their strong export oriented policies, were able not only to generate current account surpluses on sustainable basis, but as a result, also saw the value of their currencies appreciating against major currencies like the sterling pound and the US dollar.

During the period of Sri Lanka's fixed exchange rate regime, successive governments did not pursue export oriented policies continuously. There were short episodes where policies focused on export promotion, but there were more times of policy reversals towards encouraging import substitution and inward looking polices. From a long-term perspective, such polices were inconsistent with the need to maintain a fixed exchange rate regime. Under these circumstances, the key challenge the Central Bank had to face was how to defend the exchange rate peg amidst policies which did not promote exports. The only choice available for the Central Bank at the time was to restrict the use of available foreign reserves and impose severe exchange control restrictions. In a way, the Central Bank at the time was successful in maintaining low inflation, which is one of the key responsibilities of the Bank, but it failed to support the multiple objectives, which were often in conflict with each other, of the then Central Bank.

In addition to pursuing inward looking economic policies, successive governments also ran high budget deficits mainly to provide subsidies and various free entitlements. Such budget deficits, even at moderate levels, caused more demand for imports in the midst of weak export performance, creating continued current account deficits, while the Central Bank was required to maintain a fixed exchange rate regime. This was an impossible task for the Central Bank. As a result, the Central Bank, from time to time, either devalued the rupee or maintained a dual exchange rate along with severe restrictions on the use of foreign exchange. This monetary policy framework lacked credibility and created severe distortions to market pricing. Meanwhile, on the global front, the collapse of the Bretton Woods system, with the United States declaring in 1971 that it would cease to redeem US dollars for gold from its reserves, challenged the system of fixed exchange rates that the global economy was used to operate in. In addition, the 1973 oil crisis caused inflation to escalate in all countries, including Sri Lanka, often resulting in a destructive wage-price spiral. In Sri Lanka, inflation increased to 14.4 per cent by December 1973, the highest level of inflation the country experienced until then during its post-independent history.

Elsewhere in the world, following the collapse of the Bretton Woods system of exchange rates, the international community was getting used to floating exchange rates, where each currency's value was determined by the international demand for the currency. This was a new normal, prior to which money has historically been based on a valuable commodity such as gold. 


\section{Post-liberalisation Monetary Policy Framework since 1977}

In November 1977, Sri Lanka embarked on a major economic liberalisation move, marking paradigm shift from inward looking restrictive policies towards a liberal regime under which trade and payments were liberalised to a great extent. To be consistent with the new liberal regime, the Central Bank abandoned the fixed exchange rate regime and moved to a more market based system of exchange rate management. On 15th November 1977, the prevailing dual exchange rates were unified at an initial rate of Rs. 16 against the US dollar. This was an overnight devaluation of the basic exchange rate by 120 per cent! The rupee was then allowed to float under a managed exchange rate regime. Accordingly, compared to the end 1976 exchange rate of Rs. 8.83 per US dollar, the exchange rate was recorded at Rs. 15.56 at end 1977.

This sharp devaluation addressed the overvaluation of the rupee observed under the fixed regime. The subsequent managed exchange rate regime allowed some flexibility to determine the value of currency largely on the basis of market demand and supply, while attempting to prevent the overvaluation of the rupee by maintaining the real value of the rupee against movements of a basket of major currencies.

\section{The Aftermath of the Managed Float}

The introduction of the managed floating exchange rate was a welcome move from the perspective of a liberal macroeconomist. However, this resulted in new challenges to the conduct of monetary policy, particularly as the exchange rate was no longer available to anchor inflation expectations like in the past. The Central Bank also had to face a new challenge, as the government started to run extremely large fiscal deficits funded mainly by concessional external funding to develop public infrastructure such as the accelerated Mahaweli scheme. Annual fiscal deficits averaged 13.3 per cent of GDP between 1978 and 1983, External current account deficits averaged 10.8 per cent of GDP between 1979 and 1983. Year-on-year inflation averaged 15.6 per cent during February 1978 and January 1985, with a peak of 32.5 per cent in August 1980. It must be mentioned here that rising inflation was a main cause for the 1980 general strike, which resulted in over 40,000 public and private sector workers losing their jobs.

Little wonder that the Central Bank of Sri Lanka started looking for a new framework to contain inflation and inflation expectations in the absence of the pegged exchange rate system.

\section{Beginning of Monetary Aggregate Targeting in Sri Lanka}

The relationship between monetary expansion in terms of the amount of money held by the public and inflation has been well recognised in Sri Lanka from the beginning of central 
banking in the country. However, the first mentioning of "desired monetary targets" in a Central Bank annual report in Sri Lanka could be found in 1982. The 1982 annual report states that "the National Credit Plan for 1982 was formulated against the perspective of the prevailing monetary and credit policies. It attempted to rationalise the use of private sector credit among different sectors of the economy as an instrument of selective credit policy. Having taken into consideration the real growth, estimated rate of price increase and increased monetisation of the economy, the desired monetary targets were set in the Plan with a view to maintaining the consistency between financial and real output flows in the economy. The monetary targets were then translated into a permissible level of credit to the private sector by commercial banks after allowing for the impact of the behaviour of the external sector and the credit requirements of the government."

This is a classic characterisation of an annual monetary programme, which is a crucial element in monetary aggregate targeting. Based on Irving Fisher's Quantity Theory of Money, monetary aggregate targeting seeks to explain the relationship between money growth and nominal economic growth (which is the combination of real economic growth and inflation). In this framework, as monetary policy instruments attempt to influence the final objective of inflation by first affecting monetary aggregates, broad money supply was considered the intermediate target. For operational purposes, reserve money or base money, which could be influenced and monitored by the Central Bank on a daily basis, was considered the operating target. The operating target and the intermediate target, both being monetary aggregates, were linked to each other through the money multiplier.

\section{An Evolving Exchange Rate System}

While monetary aggregate targeting remained the framework for the conduct of monetary policy in Sri Lanka, the exchange rate regime also underwent a gradual evolution. The managed floating exchange rate system broadly remained a crawling band arrangement as the margin associated with the foreign exchange transactions was increased from time to time. The degree of Central Bank intervention in the foreign exchange market varied over time with balance of payments developments and the view of the Central Bank on the direction of the exchange rate.

Under this monetary targeting framework with a crawling exchange rate, achieving price stability proved challenging, as successive governments continued to run high fiscal deficits even after the completion of the accelerated Mahaweli scheme to finance large scale housing and road development programmes. In addition, the three decades of ethnic conflict required successive governments to spend more money on defense expenditure. In order to maintain competitiveness of the rupee, the Central Bank had to let the currency depreciate to, at least partly, compensate for the inflation differential between Sri Lanka and its trading partners 
under the crawling peg system. Even though this arrangement helped to alleviate the adverse impact on exports to some extent, higher domestic demand created through excessive fiscal deficits led to large current account deficits in the balance of payments, making it difficult to maintain the crawling peg without a sharp depreciation.

By the year 2000, Sri Lanka experienced a significant decline in its official international reserves, as a result of the considerable increase in expenditure on imports. The increased demand for foreign exchange placed tremendous pressure on the exchange rate. Within the managed floating exchange rate regime, this naturally resulted in increased pressure on international reserves. In order to defend the managed float, the Central Bank raised its policy interest rates to unprecedented levels, which later proved not only to be an unsuccessful exercise but also a costly experiment, which largely contributed to the only negative annual real GDP growth rate of the country's history of -1.5 per cent in 2001.

This prompted the Central Bank to revisit its exchange rate policy. On 23rd of January 2001, the Central Bank took the major step of allowing the commercial banks to determine the exchange rate depending on the supply and demand of foreign exchange in the domestic foreign exchange market. With this move, the Central Bank refrained from announcing daily buying and selling rates of foreign exchange, thus allowing freer foreign exchange transactions. The change in the exchange rate regime resulted in an overshooting effect with the rupee depreciating by Rs.13 from Rs. 98 per US dollar within the first three days, but a relatively quick stabilisation of the exchange rate followed.

As the use of monetary policy to defend the foreign exchange rate was no longer necessary under the floating exchange rate regime, the Central Bank of Sri Lanka was able to conduct monetary policy with an increased focus on achieving the Bank's objective of price stability. However, maintenance of price stability came under heavy pressure under this regime whenever aggregate demand was excessive as a result of expansionary fiscal policies.

Therefore, at times of such excessive domestic demand through fiscal dominance, the Central Bank of Sri Lanka intervened in the foreign exchange market to defend the exchange rate from depreciation. Although this was done with the good intention of maintaining macroeconomic stability in difficult times, experience repeatedly showed that managing the exchange rate extensively was always associated with a substantial loss of limited international reserves followed by a large depreciation. The most recent of such events were in 2011/2012 and 2015. During the 2011/2012 episode, the Central Bank supplied US dollars 4.2 billion to the market on a net basis, while the Central Bank supplied US dollars 3.2 billion to the market on a net basis during the year 2015. In spite of these considerable losses of reserves, the rupee depreciated against the US dollar by 13.5 per cent by the end of the 2011/2012 episode and by 9.0 per cent during 2015 . 
Since then, the Central Bank has explicitly announced that international reserves will not be used to defend an overvalued exchange rate. Instead, the Central Bank intervention in the foreign exchange market will aim to buildup international reserves. So far during 2017, the Central Bank has been able to purchase over US dollars 1.3 billion from the market on a net basis for this purpose, and improved market confidence is shown by the limited depreciation of the currency this year.

\section{Gradual Modifications to the Monetary Policy Conduct}

Returning to the previous discussion, it was clear by late 1990s and early 2000s, that a serious rethink of central banking in Sri Lanka was necessary. In addition to the increasingly popular view within international central banking and academic circles that price stability must be the overriding objective of a central bank, financial innovations, including the development of electronic payments and fund transfer systems, also prompted the Central Bank to upgrade its view on financial system stability. These factors, as well as many others which are beyond the purview of this speech, prompted the Central Bank of Sri Lanka Modernisation Project, resulting in legislative, procedural and operational changes in relation to central banking in Sri Lanka.

With regard to legislative changes, the amendments to the Monetary Law Act (MLA) in 2002 were the most important. Accordingly, the multiple objectives of the original MLA, which included stabilisation and development objectives as well as maintaining domestic and external value of the rupee, were streamlined to define the core objectives of the Central Bank as maintaining economic and price stability and financial system stability.

By this time, the Central Bank had gradually moved away from direct controls to market based tools of monetary policy, a process which started with the adoption of open economy policies since 1977. The significant advancement in monetary policy operations during this period was the introduction of the Repurchase rate and the Reverse Repurchase rate of the Central Bank. The Central Bank introduced its repurchase facility in 1993 to mop up overnight excess liquidity from the market, while introducing the reverse repurchase facility in 1995 to inject overnight liquidity to the market. These two rates served as the floor and the ceiling for movements of the interbank call money market rate. This policy interest rate corridor was used from early 2000s to signal changes in the monetary policy stance of the Central Bank. Today this policy corridor is called the Standing Rate Corridor with the floor and the ceiling rates being known, respectively, as the Standing Deposit Facility Rate (SDFR) and the Standing Lending Facility Rate (SLFR) of the Central Bank of Sri Lanka. Open market operations are conducted in a more active auction based framework with overnight, short-term and longterm operations to maintain market liquidity and thereby market interest rates in line with the announced monetary policy stance of the Central Bank. 
The key operational changes to the conduct of monetary policy included the establishment of the Monetary Policy Committee (MPC) of the Central Bank in 2001 to strengthen monetary policy analysis and to improve the transparency of the decision making process. The Central Bank also began issuing regular press releases on monetary policy decisions to the public, based on an advance release calendar. This press release was often followed by a press conference chaired by the Governor and accompanied by the senior officials of the Central Bank. The Central Bank also introduced a Monetary Policy Consultative Committee (MPCC) comprising academics, professionals and private sector representatives, enabling the Central Bank to obtain views of the private sector to be used in the monetary policy formulation process. In addition, the Central Bank started to enunciate its monetary and financial policies for a medium-term horizon though a Road Map, which was unveiled at the beginning of each year.

\section{105 Consecutive Months of Single Digit Inflation}

In spite of these modifications to the framework of conducting monetary policy over time, Sri Lanka continued to suffer from double digit inflation until 2009 as a combined outcome of high budget deficits and loose fiscal policy, reactive rather than proactive monetary policy, frequent domestic supply disruptions and international commodity price shocks. In June 2008, inflation increased to 28.2 per cent, the highest level of inflation since 1980s. In order to manage this situation within the monetary targeting framework, the Central Bank used strict quantitative monetary targets with increased policy interest rates while also imposing restrictions on access to the Central Bank reverse repurchase facility. In a display of validity of monetary targeting, the Central Bank was able to bring down inflation from the peak to near zero levels within a 12-month period. It was the sharpest disinflation the country has experienced in the history of Sri Lanka, but it must also be noted that the weak global commodity prices also contributed to this decline to some extent.

Nevertheless, the intent of the Central Bank to maintain inflation at mid-single digit levels, which was made clear through action as well as through communication, enabled the Central Bank to change the mindset of the people that Sri Lanka is typically an economy with double digit inflation. The change in the mindset was visible in improving inflation expectations. Since February 2009, inflation has remained in single digits, and 105 consecutive months of single digit inflation is considered an achievement in the recent history of Central Banking in Sri Lanka.

\section{Infeasibility of Monetary Aggregate Targeting}

However, Sri Lanka's achievement of single digit inflation for 105 consecutive months had little to do with monetary aggregate targeting. From July 2009 to September 2017, the year- 
on-year broad money growth was, on average, 17.1 per cent. Year-on-year inflation during the same period averaged 5.2 per cent. Based on the earlier discussed Fisher's Quantity Theory of Money, the gap between these two figures, that is 11.9 per cent, must reflect average real economic growth during this period. However, real economic growth averaged only 6.0 per cent during this period. If the argument is reversed, there is a gap of 11.1 per cent between broad money growth and real economic growth. According to the Quantity Theory, this should reflect average inflation during the period, which was not the case. Even if some allowance is made for changes in velocity of money or money demand due to possible behavioral changes and financial sector development, the growth of money vs. the real growth of the economy and inflation cannot be explained for this period.

This was sufficient evidence that the strong and reliable relationship between the goal of price stability and the nominal anchor of money growth, which was essential for the success of the monetary aggregate targeting framework, has significantly weakened over time. This phenomenon was not limited to Sri Lanka, but was observed over time in many other economies as well. With the ending of monetary aggregate targeting in Canada in as early as 1982, Gerald Bouey, Bank of Canada Governor at the time famously stated "we did not abandon monetary aggregates. Monetary aggregates abandoned us." Even the recent experience with quantitative easing in many advanced economies yet again proved that the tremendous expansion of central bank balance sheets that these countries undertook was insufficient to raise either growth or inflation.

Earlier it was argued that Sri Lanka's achievement of single digit inflation for 105 consecutive months had little to do with monetary aggregate targeting. Instead, it was a result of the Central Bank's ability to anchor inflation expectations, by repeatedly emphasising its utmost desire to maintain inflation at mid-single digit levels. The behaviour of the Central Bank during the 2008-2009 episode of disinflation would have raised credibility of monetary policy. Improved communication also would have played a key role in this achievement. It must be noted that the neighbouring economies struggled with double digit inflation during some parts of the same period. For example, India was unable to tame inflation until 2014. One might argue that international commodity prices were in our favour. However, this was not always true, as global crude oil prices remained, on average, above US dollars 100 per barrel during the period from February 2011 to September 2014.

\section{Inflation Targeting as an Alternative: Lessons from Other Countries}

Therefore, without a formal announcement, the Central Bank of Sri Lanka, similar to many other central banks in the world, has moved to a monetary policy framework governed by expectations and credibility, rather than by monetary aggregates or exchange rates. 
In the global economy, such a monetary policy framework that emphasised the role of expectations and credibility existed, and it was known as "inflation targeting" that I briefly referred to at the beginning. First adopted by New Zealand in 1990, inflation targeting was chosen as the monetary policy framework in Canada, the United Kingdom, Australia, and Sweden in quick succession. Encouraged by the success of inflation targeting, a number of other advanced economies as well as emerging market economies adopted this framework thereafter. These countries used inflation targeting either to bring down inflation from stubbornly high levels or to maintain inflation at low and stable levels on a sustained basis.

Inflation targeting is generally characterised by an announced inflation target; an inflation forecast, which facilitates forward looking monetary policy decision making; and a high degree of transparency and accountability. According to Lars Svensson, the Swedish economist who later served as Deputy Governor of the Riksbank, this policy framework encompasses a trinity of a mandate for price stability, independence, and accountability for the central bank, which enables anchoring of inflation expectations effectively.

In practice, inflation targeting is flexible rather than strict. According to Svensson, flexible inflation targeting means that monetary policy aims at stabilising both inflation around the inflation target and the real economy, whereas strict inflation targeting aims at stabilising inflation only, with little regard to the stability of the real economy. A strict inflation targeter would be who Mervyn King, the former Governor of Bank of England, called an "inflation nutter". Most of the central banks do not only aim at stabilising inflation around an inflation target, but also put an effort into stabilising real economic variables. This effort is described by the time horizon in achieving the inflation target, which dampens the adverse impact of policies on the real economy. Therefore, an important feature of flexible inflation targeting is that the inflation rate will be on average at target, but perhaps not every month.

A key advantage of inflation targeting is that it is easier for the general public to relate to. Since inflation is well understood by the public, the inflation forecast will serve as an ideal anchor and, with improved communication, will help bridge the information gap between the central bank and the public. Reference to such a straightforward target, rather than to an elusive monetary target, will ensure increased transparency and accountability while enabling the public to understand policy shortcomings.

Global experience has also shown that in adopting inflation targeting, a country needs to fulfill several prerequisites, particularly in terms of the legal and institutional framework. These include central bank independence and strong mandate for price stability, strong fiscal position with freedom from fiscal dominance, a flexible exchange rate regime, a well-developed financial system, a sound technical infrastructure for inflation forecasting, and transparent policies to build accountability and credibility of the central bank. In particular, with regard to fiscal dominance, other countries had developed mechanisms to stop monetary financing of fiscal deficits, particularly through subscribing to government securities auctions and the 
provision of interest free funds to the government through an advance account as observed in Sri Lanka. Instead, other central banks would purchase government securities from the secondary market to influence monetary conditions as and when necessary.

\section{Road to Flexible Inflation Targeting: Where We Stand}

Considering the success of flexible inflation targeting in advanced and emerging markets, the Central Bank of Sri Lanka also considered this as the best framework to be adopted in the medium-term. A number of prerequisites for the new framework have already been fulfilled by the Central Bank and the government during the past few years with the view of moving towards flexible inflation targeting in the medium-term.

At present, as an interim arrangement, the Central Bank conducts its monetary policy within an enhanced framework with features of both monetary aggregate targeting and flexible inflation targeting frameworks. Under this enhanced monetary policy framework, the Central Bank focuses on stabilising inflation in mid-single digits over the medium-term, while supporting the growth objectives and flexibility in exchange rate management. Although the Central Bank does not announce any monetary targets explicitly, broad money aggregates remain a key indicative intermediate variable to guide the conduct of monetary policy. Moreover, instead of reserve money, the Central Bank currently uses the average weighted call money rate (AWCMR) as its operating target and increasingly relies on its market based policy instruments, namely policy interest rates and OMO.

As accurate forecasts of inflation and other key variables are essential for the success of flexible inflation targeting, macroeconomic projection capabilities of the Central Bank are currently being strengthened. As an important step toward building technical infrastructure for the successful implementation of flexible inflation targeting, a Forecasting and Policy Analysis System (FPAS) using short-term forecasting tools and medium-term dynamic stochastic general equilibrium (DSGE) techniques, has been developed by the Central Bank with the assistance of the International Monetary Fund (IMF). This system is currently being integrated into the monetary policy formulation process of the Central Bank. Following the best practices among inflation targeters, the number of Monetary Policy Committee (MPC) meetings has been reduced to eight meetings per year in order to provide technical staff sufficient time for deeper macroeconomic analysis.

Several other recent policy changes will also support the implementation of flexible inflation targeting in the medium-term. The Central Bank has implemented a more market based exchange rate policy during recent times, with limited intervention in the foreign exchange market. There has been a build-up of international reserves with minimal impact on the exchange rate. In tandem, the financial system has continued to expand whilst exhibiting resilience amidst challenging market conditions both globally and domestically. The 
implementation of the Basel III framework will further enhance the resilience of the financial system.

A deeper and more liquid government securities market is also a prerequisite for a smoother transmission of the Central Bank policy rate signals to market interest rates, as yields on government securities form benchmark medium to long-term interest rates. In this regard, the recently introduced system of rule based and more transparent Treasury bond auctions, has not only reduced sharp volatility in yields on government securities, but also corrected the distortion between Central Bank policy rates and market interest rates that existed earlier. This mechanism has also helped reduce monetisation of the fiscal deficit through purchasing Treasury bills by the Central Bank at primary auctions. For example, the Central Bank holdings of Treasury bills have declined drastically this year from more than Rs 300 billion at end 2016 to around Rs 40 billion by now, as the new system ensures full market subscription through the auction system without creating adverse volatility in interest rates. The proposed Liability Management Act allows the Treasury to create a buffer fund to meet the expenditure in the following year, eliminating the necessity for the Central Bank to provide advances to the Treasury at the beginning of each year as per the current provisions of the MLA. These two measures would, in future, insulate monetary policy from fiscal dominance. These reforms are expected to create a win-win situation for both the Central Bank and the Treasury, as they would facilitate the Treasury to raise the required funds at the least possible cost from a more sophisticated government securities market at competitive rates, while helping the Central Bank to achieve its primary objective of maintaining price stability.

\section{Looking towards the Future: Flexible Inflation Targeting as the New Monetary Policy Framework}

In the "Road Map: Monetary and Financial Sector Policies for 2017 and Beyond" presented in January 2017, the Central Bank of Sri Lanka reiterated its intention to move to flexible inflation targeting in the medium-term as its new monetary policy framework. The government has endorsed this move since then, and stated in its recently released Vision 2025 policy document that "for medium to long-term price stability, the Central Bank will move towards a flexible inflation targeting regime. They will aim at continuously maintaining low inflation while supporting economic activity and competitiveness. The government will implement the legislative and operational changes necessary."

While it is heartening to note that the Central Bank and the government have agreed in principle that flexible inflation targeting is the way forward in the conduct of monetary policy, the full implementation of flexible inflation targeting by the year 2020 will require increased efforts to fulfil the remaining prerequisites for the success of inflation targeting. 
It is also expected that comprehensive amendments will be made to the MLA to facilitate the transition to flexible inflation targeting, to redefine monetary policy objectives, eliminate monetary financing of fiscal deficits, and ensure Central Bank autonomy and public accountability. Amendments to the MLA are also expected to streamline the monetary policy decision making process.

Within the Central Bank, the ongoing upgrade of technical forecasting and analytical capabilities will continue, and it is expected that by 2020, the Central Bank will commence the publication of comprehensive Inflation Reports. The Inflation Report will explain inflation developments, inflation expectations, projections for inflation and other key macroeconomic variables, the assumptions behind such projections, reasons for any deviation of actual inflation developments from targeted levels, and remedial actions to be taken in the case of deviations. Such transparency and accountability is likely to enhance the credibility of the Central Bank and well anchor inflation expectations, resulting in increased economic stability and supporting high economic growth and increased international competitiveness of Sri Lanka.

Meanwhile continued commitment by the government towards greater fiscal discipline and stronger fiscal position remains key to the successful adoption of flexible inflation targeting. Therefore, the Central Bank will continue to support government's efforts to reduce the debt to GDP ratio to 70 per cent by 2020 and curtail budget deficits at 3.5 per cent of GDP from 2020. The government's intention to strengthen the Fiscal Management (Responsibility) Act is very encouraging in this regard.

In conclusion, I would like to take you back to the beginning of Central Banking in Sri Lanka. In 1949, John Exter, the founder of the Central Bank of Sri Lanka, in his "Report on the Establishment of a Central Bank for Ceylon" stated as follows:

"The decision of the government of Ceylon to establish a central bank was a decision with far reaching implications for the people of Ceylon. One implication already stands out very clearly: in taking steps to establish an independent monetary system to be administered by a central bank the government has demonstrated unmistakably its intention to achieve genuine economic freedom as a corollary of the political freedom achieved a year and a half ago. It has been the endeavour of this report to propose a type of central bank which, with proper skill and understanding in its management, will establish monetary conditions in Ceylon that may make possible, as never before, the fuller use of the nation's human and material resources and a rising standard of comfort for all."

History has judged us before! I will leave it up to you to judge us in future as well! 


\section{Bibliography}

Bernanke Ben S., and Michael Woodford (eds). The Inflation Targeting Debate. Cambridge Massachusetts, National Bureau of Economic Research Studies in Business Cycles, 2005.

Bernanke, Ben S., Thomas Laubach, Frederic S. Mishkin, and Adam S. Posen (eds). Inflation Targeting. Princeton, Princeton University Press,2001.

Blinder, Alan. Central Banking in Theory and Practice. Cambridge Massachusetts, The MIT Press, 1996.

Central Bank of Sri Lanka. 40th Anniversary Commemorative Volume of the Central Bank of Sri Lanka, 1950-1990. Colombo, Central Bank of Sri Lanka, 1990.

Central Bank of Sri Lanka. 60th Anniversary Commemorative Volume of the Central Bank of Sri Lanka, 1950-2010. Colombo, Central Bank of Sri Lanka, 2011.

Central Bank of Sri Lanka. Annual Report. Various Years.

Central Bank of Sri Lanka. Road Map: Monetary and Financial Sector Policies, Various years.

Colombage, Sirimevan. The Political Economy of Central Banking in Sri Lanka. Prof. H. A. de S. Gunasekera Memorial Oration, University of Peradeniya, October 2017.

Government of Ceylon. Sessional Paper XIV: Report on the Establishment of a Central Bank for Ceylon (Exter Report). 1949.

Government of Sri Lanka. Vision 2025: A Country Enriched. 2017.

Gunasekera, H.A. de S. From Dependent Currency to Central Banking in Ceylon: An Analysis of Monetary Experience, 1825-1957. London, G. Bell and Sons, Ltd., 1962.

Irwin, Neil. The Alchemists: Three Central Bankers and a World on Fire. New York, Penguin Group, 2014.

Ito, Takatoshi, and Andrew K. Rose. Monetary Policy under Very Low Inflation in the Pacific Rim. NBER-EASE, Volume 15, Chicago, University of Chicago Press, 2006.

Karunatilake, H.N.S. Fifty Years of Central Banking in Sri Lanka: 1950-2000. Colombo, Centre for Demographic and Socio Economic Studies, 2000

King, Mervyn A. Changes in UK Monetary Policy: Rules and Discretion in Practice. Journal of Monetary Economics, 39(1), 1997, pp. 81-97.

Mishkin, Frederic S. Monetary Policy Strategy. Cambridge Massachusetts, The MIT Press, 2009.

Schaechter, Andrea, Mark R. Stone, and Mark Zelmer. Adopting Inflation Targeting: Practical Issues for Emerging Market Countries. Washington DC, International Monetary Fund, 2000.

Svensson, Lars E. O. Flexible Inflation Targeting: Lessons from the Financial Crisis. Speech made at the Netherlands Bank workshop "Towards a new framework for monetary policy? Lessons from the crisis", September 2009. 
Svensson, Lars E. O. Open-Economy Inflation Targeting. Journal of International Economics, 50, 2000, pp. 155-183.

Weerasinghe, P. Nandalal. The Role of Central Banks in in Macroeconomic and Financial Stability: Global and Local Perspectives. Speech made at the Centre of Banking Studies in Sri Lanka, January 2013.

Wijewardena, W.A. Central Banking: Challenges and Prospects. Colombo: BMS Publication, 2017. 


\section{Annexure}

\section{Chart 1: Real GDP Growth}

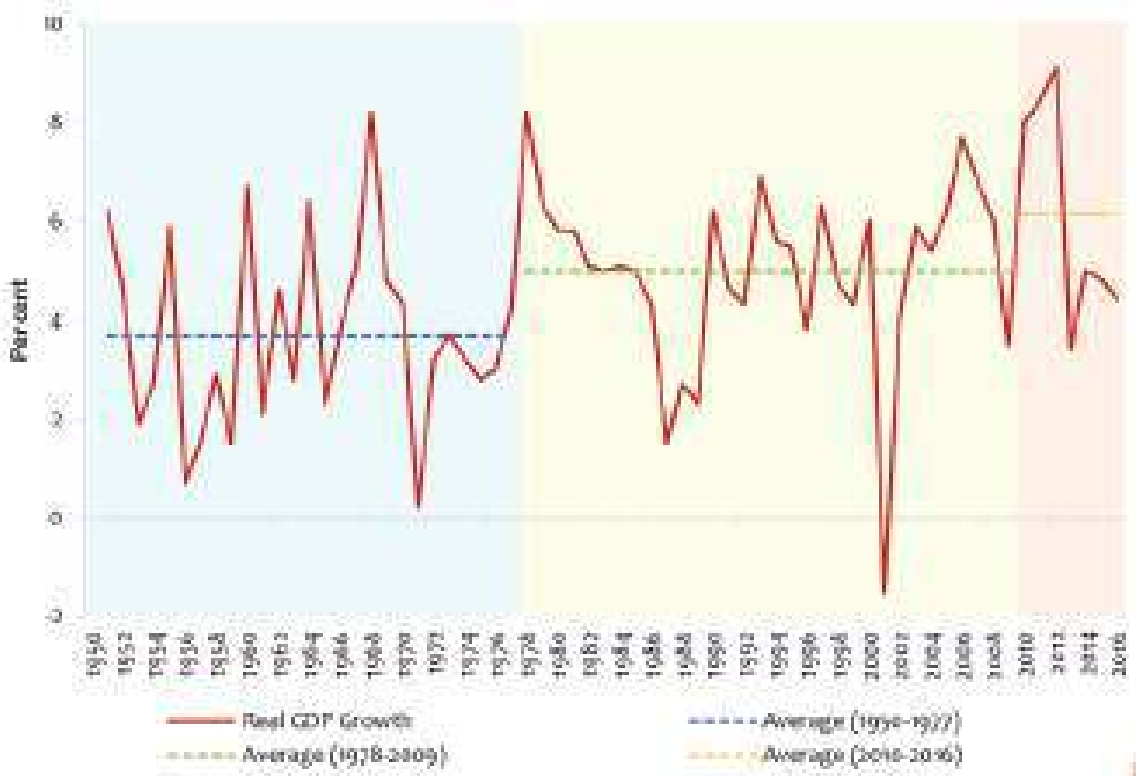

\section{Chart 2: Annual Average Inflation}

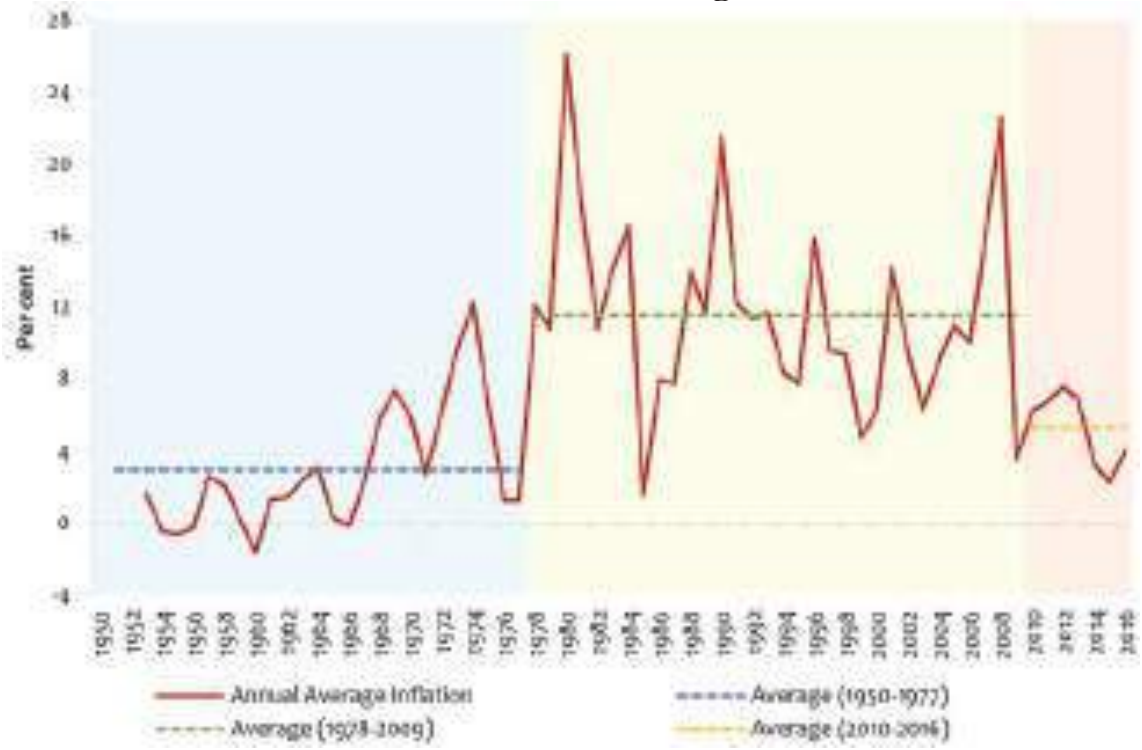




\section{Chart 3: Budget Deficit}

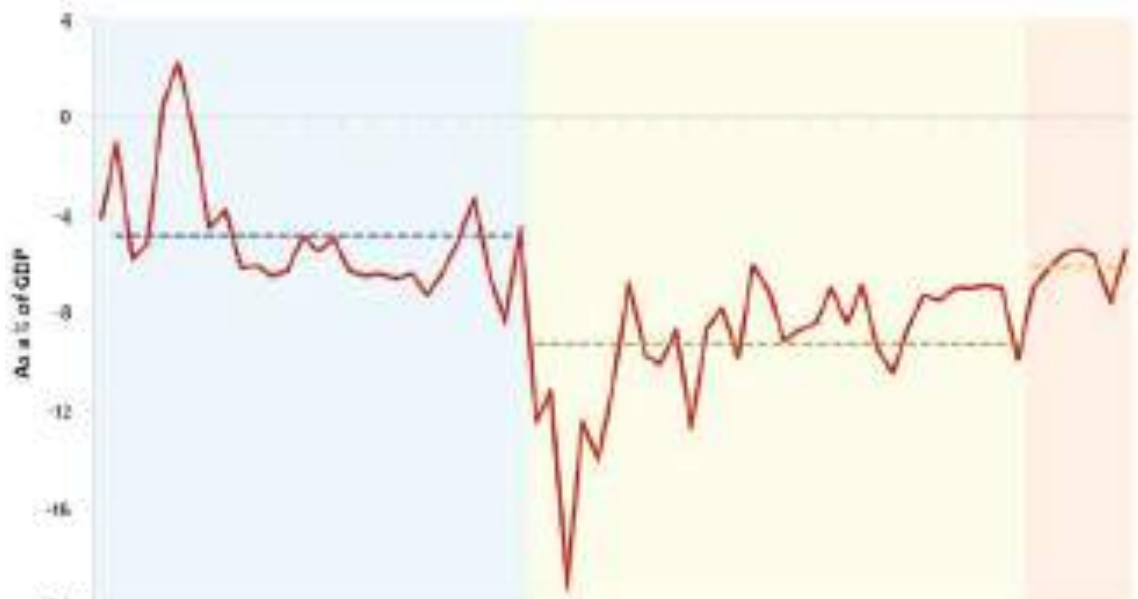

$-30$

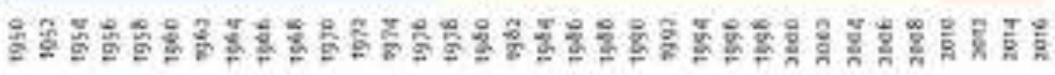
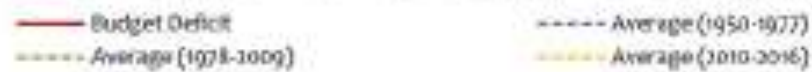

2...... Averape (3010.9016)

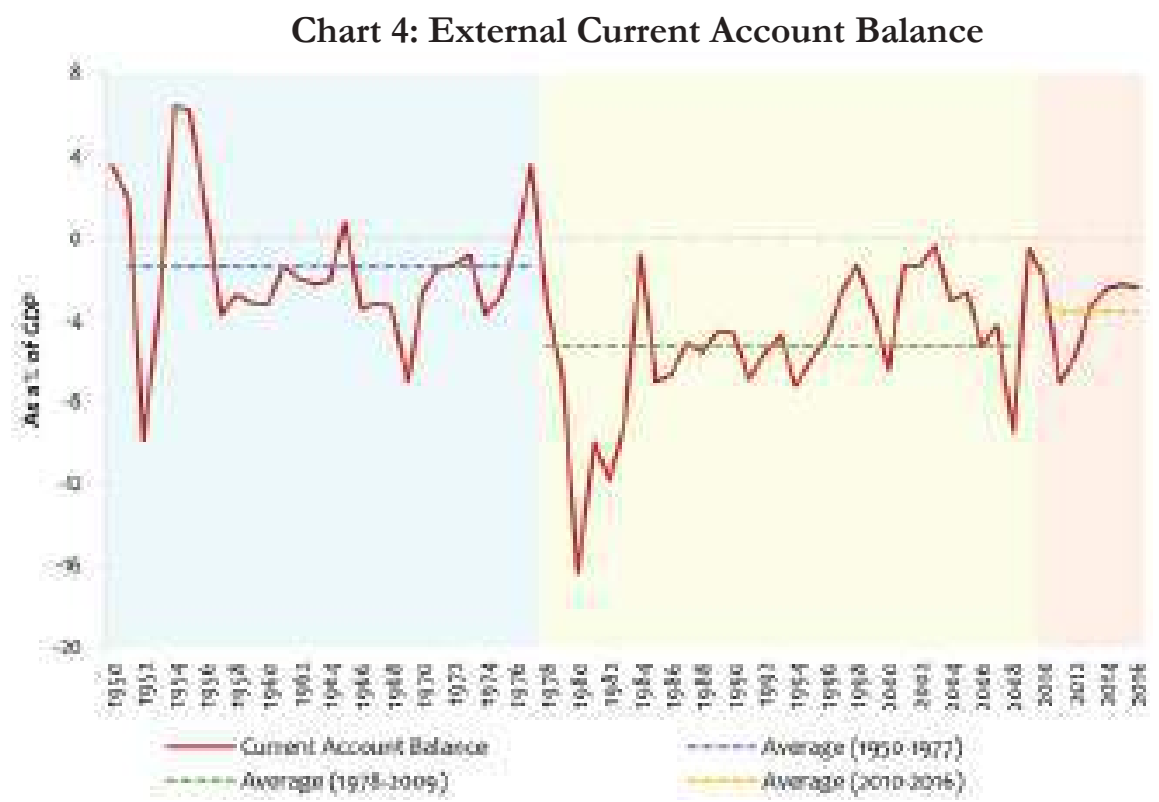

